\title{
The Value Of Islamic Inheritance In Consolidation Of The Family Financial Stability.
}

\author{
Salako Taofiki Ajani ${ }^{1}$, Bhasah Abu Bakar ${ }^{2}$, Mikail Ibrahim ${ }^{3}$ \\ ${ }^{I}$ (Department of Religious Studies, Tai Solarin University of Education, Ijebu-ode, Ogun State, Nigeria). \\ ${ }^{2}$ (Faculty of Major Languages, University Sains Islam Malaysia). \\ ${ }_{3}^{3}$ (Faculty of Major Languages, University Sains Islam Malaysia).
}

\begin{abstract}
Islamic Inheritance is observed to be an aspect of the Islamic teachings which Muslims in Nigeria particularly in the South West find extremely difficult to operate. This is not because they do not believe in the principle but because the attendant customs and cultural practices have great influence on the inheritance practices of the people.The crisis and atrocities which the customary law of inheritance has unleashed on the people in the area are enormous. This ranges from forceful denial of rightful owners to their people's property e.g. son's denial of inheritance to his parent's property, wife's denial of inheritance to her husband's property or vice versa as the case may be. Further atrocities perpetrated on the struggle for inheritance include deliberate killings of legal heirs, maiming and total destruction of life and property to mention a few. The nonoperation of Islamic inheritance among the Muslims in the area is a kind of deficiency in line with the Quranic verse that says, 'will you believe in some parts of the Quran and show disbelieve to the others?' Adopting islamic inheritance as a means of practically following Allah's injuction is justified in this paper.
\end{abstract}

Keywords. Islamic inheritance, family financial stability.

\section{Introduction.}

Mirath means inheritance to be shared from the property of the deceased among his successors. The study of Mirath in shariah gives rules as to who inherits and who is to be inherited and what shares go to the heirs. The death of a person brings about transfer of most of his rights and obligations to persons who survive him and are called Wuratha that is heirs and representatives. (Abdul Hamid Siddiqui 2005). [1]

There are about thirty-five verses of the Quran which refer to Mirath or its derivatives in one form or the other e.g Quran says,

"And Allah will be the One to inherit everything in the heavens and the earths and to him belong the knowledge of the hidden".

Abdul Hamid Siddiqui (2007) [2] defines inheritance as when living persons rightfully acquire dead persons' property'. Yushua Sodiq (1996) [3] quoting P. C. Lloyd asserts that inheritance is the transference of status from the dead to the living person with respect to specific property objects.

The purpose of this research is to point out the need to practically adopt the practices of the institution of inheritance in Islam as a measure to checkmating the atrocities that accompany the customary practices of inheritance in the focused area. Adopting and operating whole heartedly the Islamic inheritance as laid down by Allah will save destruction of lives and properties, it will inject love among inheritance sharers, gives room for equitable distribution of wealth because God's law will be used and studies have shown that God is impartial in his distribution of property. Its purpose is also to simplify Islamic principles of inheritance to those who lack knowledge of it in order to amend their deficiency in religious practices.

\subsection{Pre - Islamic Customary Conventions of Inheritance.}

Rules and customs of succession of Arabia before Islam were similar to that of the West African countries. Highlights of these customs were total restriction of females from inheritances. Females were as well reduced to property to be sold, bought and inherited and even assigned as payment of debts. [4]

Inheritance was mainly for man, fictitious relationship by adoption, oath of brotherhood and patronage were common and boys below the age of puberty could not inherit.

In the words of Abdul Hamid Siddiqui (2007 p.2),

"In pre-islamic Arabia, and other countries where there had been tribal societies, not only were women deprived of the right to inheritance but even weak and sick persons and minors (children) were given no share in the inheritance. The common practice was that "he alone is entitled to inherit who wields the sword."

The Islamic reform rebuilt the rules of succession and introduced equality among the sexes in accordance with their natural position. These were based upon the principles that the property of the deceased 
should devolve on those who have the strongest claim to be benefited by it and in proportion to the strength of such claim with harmonious distribution of estates among the claimants.

\subsection{Islamic Law of Inheritance.}

The Islamic law of Inheritance is called IImul - faraid or IImul mirath and the verses of the Quran upon which the law is based begins from (Quran 4: verse 11) which goes thus:

"God (thus) directs you as regards your children's (inheritance) to the male, a portion equal to that of two females: if only daughters, two or more, their share is two-thirds of the inheritance: if only one, her share is a half. For parents, a sixth share of the inheritance to each, if the deceased left children, if no children, and the parents are the (only) heirs, the mother has a third, if the deceased left brothers or (sisters) the mother has a sixth. The distribution in all cases is after the payment of legacies and debts; ye know not whether your parents or your children are nearest to you in benefit. These are settled portions ordained by Allah: and Allah is All Knowing, All - wise.” This law of inheritance continues in verse 12 of the same Surah thus:

"In what your wives leave, your share is a half, if they leave no child, but if they leave a child, ye get a fourth, after payment of legacies and debts. In what ye leave, their share is a fourth, if ye leave no child, but if ye leave a child, they get an eighth, after payment of legacies and debts. If the man or woman whose inheritance is in question has left neither ascendants nor descendants, but has left a brother or a sister, each one of the two gets a sixth, but if more than two, they share in a third, after payment of legacies and debts, so that no loss is caused (to anyone). Thus is it ordained by Allah, and Allah is All - Knowing, Most Forbearing".

Stephen Sapp (1996) [5] opines that the essence of these verses are to moderate the economic differences between the haves and have -nots, i.e. to keep wealth in circulation and to encourage its distribution among many people. Showing how important, compulsory and beneficial the law of inheritance is in Islam, the Prophet was reported to have said, "Learn the knowledge of inheritance and teach the knowledge of inheritance for it is a half of knowledge". (Islam and inheritance 2009). [6]

Also, Umar bn Khattab was reported to have said, "O people, learn Fara-id with the same concern and effort with which you learn from the Quran". In another area, it was reported that he used to say. "O Muslims, learn Fara-id, it is an essential part of the knowledge of your religion"'. [7]

The muslim concept of financial organization include the husband, wife, children, and relatives including the maternal and paternal relations. This broad family relationship makes it co-operative in social considerations. The duty to support poor relations fall upon wealthy relatives and inheritance is for all relatives with the priority on blood ties before others.

Ownership of property from a deceased relation is called ownership by succession, so the law of succession may be optional or compulsory. The former stems from the Waziya (Will) while the latter is from the Quran. Inheritance according to Quran comes into operation by three ways, namely:
(i) Nasab
(ii) Nikkah
(iii) Wallah.

\section{Means of Ownership-to-Succession.}

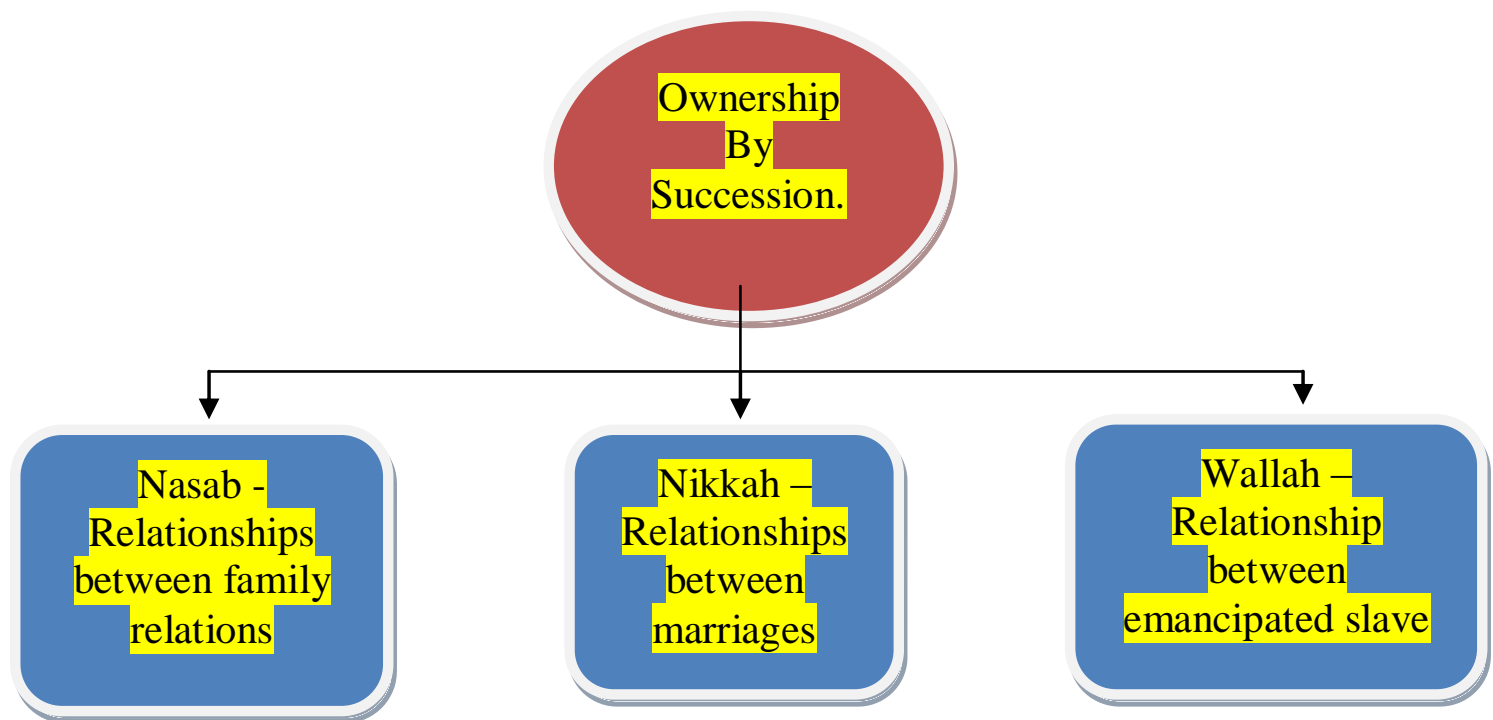

(i). Nasab means relationship between relatives: father, mother, children, brother, sister, etc.

(ii). Nikkah: This is relationship between marriages. i.e wife or husband. 
(iii).Wallah: This means relationship between an emancipated slave and an emancipator.

According to Yushua Sodiq (1996 p9), "three categories of heirs are recognized in Islam, the primary, secondary and substitute heirs"'. [8]

To him, primary heirs include the spouses, children and parents. Secondary heirs are the agnate grandsons, agnate granddaughters, agnate grandfathers and grandmothers while the substitute heirs take the shares of those whom they substitute in the absence of the primary heirs.

The Quran mentions nine types of relatives as inheritors. [9]

Muhammad Abdul Rauf (1999) [10] in his book Inheritance in Islam supplies details of relations who are to pertake in inheritance as sons, daughters, son's sons, son's daughters, husband, wives, father, mother, father's father, grandmother, full brothers, full sisters, paternal brothers, paternal sisters, maternal brothers or sisters, full bothers' son etc.

Most of the scholars agree that before the deceased property could be shared among his survivors, the following five rights in order of preference should be observed: Abdul Hamid Siddiqui, William A. Coggins (2004), [11] Adil Salahi (2004). [12]

i. Settle his mortgages

ii. Pay his funeral expenses

iii. Finding out if he has debts to pay and pay it without delay.

iv. Execute his will if he has willed certain things to certain people not exceeding one - third of the property

v. Distribute the remaining property among the heirs in line with the Islamic law.

To Hanafi and Mliki schools, mortgaged property is not shared until cleared. But Hambali and Shafihi said that they should distribute it to the heirs who will balance the mortgage under the supervision of the judge.

\subsection{Impediments to Succession.}

Impediments are the barriers or conditions which may disallow the legal heirs from inheriting from the property which a deceased left behind. These could be grouped into three categories.

\section{Impediments Against Islamic Inheritance.}

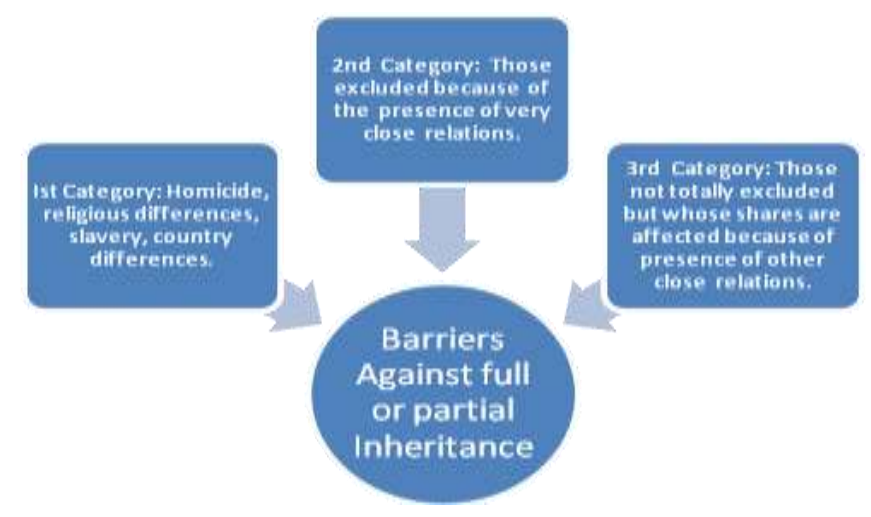

3.1.1.First Category:- These include persons who are disallowed because of certain acts or reasons.

3.1.1.1. Homicide:- This refers to a person who causes the death of another person. He cannot inherit no matter how relatively close he may be to the deceased if he is discovered to be the killer of the deceased e.g child- parent, husband - wife etc. In the words of Dr. Abid Hussain, ( 200 8, p1), [13] "Heirs may also be prevented from inheriting by disqualification. The only two practical situations which are causes of disqualification are difference of religion and homicide".

3.1.1.2. Differences of Religion:- A muslim cannot inherit a non-muslim and vice versa.

However, one who shares a different religious view from the deceased may enjoy from Waziyah (will) which cannot be more than one-third of the whole property. Prophet Muhammad (SAW) was reported to have said that a muslim cannot inherit a non-muslim and vice versa.

3.1.1.3.Slavery:- A slave cannot inherit from his free deceased relative because there is no likelihood of equal reciprocity between the two. This is because; the slave owns practically nothing due to his state. If a deceased is to be inherited by only slaves, some jurists said that the property should be sold to free the slave while some are of the opinión that the property should go to the public treasury.

3.1.1.4.Difference of Abode:- A muslim living in another country different from that of the deceased cannot inherit from the property of the deceased. This is because, laws of the countries could be different due to some international regulations may not favour each other inheriting from either party. 
3.2.1.Second Category:- These include legitimate heirs who are excluded completely from inheritance because of the intermediary of other relatives closer in lineal proximity to the deceased e.g a relative of the second grade like the grandparent of the deceased does not inherit if the parent who is the first grade heir is present. To this, Dr. Abid Hussain (2008 , p3) [14] says, "an individual nearer in degree (proximity) to the deceased excludes the one who is remoter within the same class of heirs ( son excludes grandson)"'.

3.3.1.Third Category:- This category consists of heirs whose shares may vary but not entirely excluded due to the presence of other heirs e.g the husband's share depends on whether the deceased wife left any issue or not and vice versa. Mother's of father's share in iheritance depends on whether the wife or husband had an issue or left behind any child either from the deceased or from another husband or wife as the case may be. Sister's or brother's share depends on whether or not the deceased whose property is to be shared left behind any child or not.

\subsection{Division of Heirs in Islamic inheritance.}

In Islamic inheritance, heirs are mainly divided into 3:

(i). Quranic heirs

(ii). Agnatic heirs

(iii). The Distant kinsmen.

Three Groups of Heirs in Islamic Inheritance.

\section{Quranic Heirs \\ Agnatic Heirs \\ Distant Kinsmen}

4.1.1.Quranic Heirs:- They are those whose shares are specifically mentioned in the Quran. The property of the deceased goes to the Quranic heir and if the estate is not exhausted, then it goes to the Agnatic heirs and in the absence of the Agnatics, it goes to the Distant Kinsmen.

Quranic Heirs consist of close relations to the deceased to whom specific shares are allotted in the Quran such as $1 / 2,1 / 4, \frac{1}{6}, \frac{1}{8}, \frac{2}{3}$.

As the shares are fixed by the Quran, they take precedence over the other two classes. The Quranic heirs consist of males and females.

4.1.2.Agnatic Heirs: - These were the principal heirs before Islam. They still remain in the law of inheritance if the claim of lawful relations mentioned in the Quran are satisfied by giving each of them their satisfied portion. The son, brother, paternal uncle are in this group.

4.1.3.Distant Kinsmen: These are people of the deceased who are not Quranic sharers or agnatics. According to Maliki school, the male heirs are ten, and females seven in number. Males are son, grandson, father, paternal grand father, brother, brother's son, paternal uncle, husband, patron, son of paternal uncle.

Females are: daughter, son's daughter, mother, grandmother, sister, wife and patroness.

\subsubsection{Fractional Shares of Islamic Inheritance.}

Fractionals shares of Islamic inheritance are represented as follow:

Fractional Shares of Islamic Inheritance.

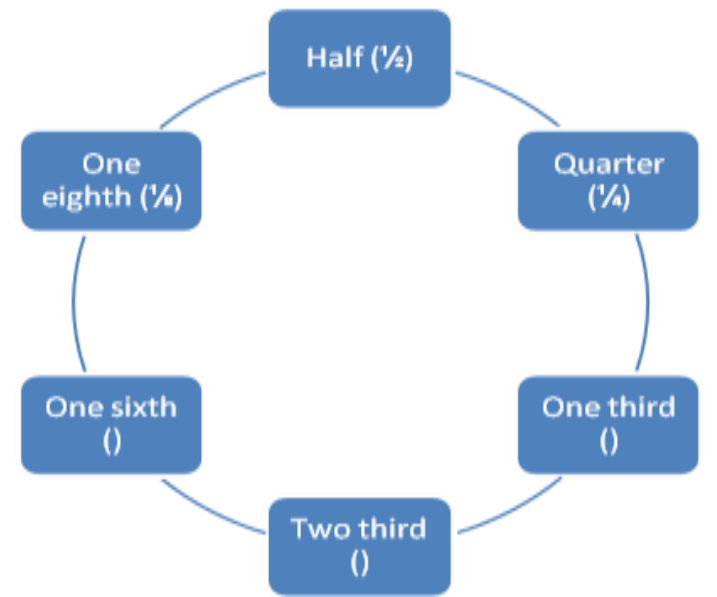




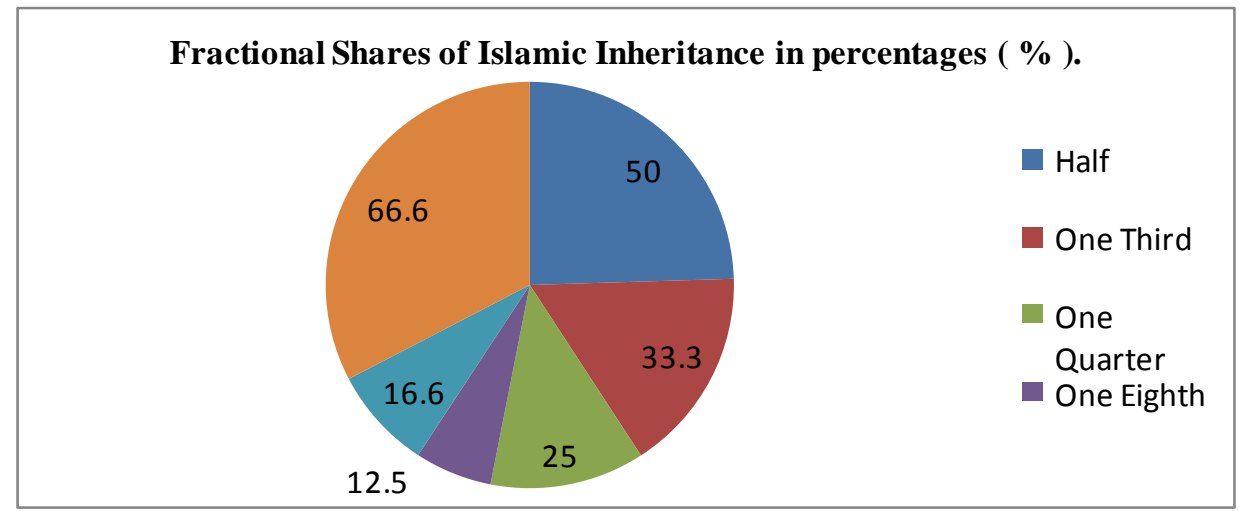

\subsubsection{Those entitled to $1 / 2$ (half) shares of inheritance.}

Half $(1 / 2)$ of wife's inheritance is to be given to the husband when the wife has no issue or grand daughter; the daughter also takes half ( $1 / 2)$ of her parent's inheritance if she is the only one, but where she has got a brother or a sister, she is not entitled to $1 / 2$. Also the grand daughter takes half ( $1 / 2)$ shares of what is entitled to her mother where the mother is dead and she is taking her position when she is alone and her father is not living.

If somebody (wife) died leaving behind the husband and uncle, the husband takes $1 / 2$ shares and the uncle takes the Agnatic's share.

If somebody (father or mother) died leaving a daughter and a cousin behind, the daughter takes $1 / 2$ shares and the rest goes to the cousin i. e (1 -1) share equally.

If a person (wife / mother) died and left behind a husband and a daughter, the husband takes $1 / 4$ shares and daughter takes $1 / 2$ shares.

\subsubsection{Those entitled to $1 / 4$ shares of inheritance.}

The wife of a deceased is to take $1 / 4$ shares if the husband has no issue. Also, the husband takes $1 / 4$ shares where the wife has issue or issues.

\subsubsection{Those entitled to $\frac{1}{3}$ shares of inheritance.}

Father is to take $\frac{1}{3}$ shares of inheritance when there are no issues from the deceased (son or daughter). Mother also takes $\frac{1}{3}$ shares if there are no issues from the deceased son or daughter) but where there are issues both of them will take $\frac{1}{6}$ shares each.

\subsubsection{Those entitled to $\frac{2}{3}$ shares of inheritance.}

Two or more immediate daughters of the deceased when no sons. Two sisters or more related to the deceased when no issues from the deceased.

\subsubsection{Those entitled to $\frac{1}{6}$ shares of inheritance.}

Father takes $\frac{1}{6}$ shares if there are issues from the deceased. Also, mother takes $\frac{1}{6}$ shares if there are issues from the deceased. Grandmother takes $\frac{1}{6}$ shares when there are immediate daughters of the deceased and she is taking the position of her daughter claiming her daughter's shares of inheritance. And grand - father takes $\frac{1}{6}$ shares when there is no father for the deceased and he the grand-father is claiming the inheritance shares of his own son but who is father to the deceased.

\subsubsection{Those entitled to $\frac{1}{8}$ shares of inheritance.}

Wife takes $\frac{1}{8}$ shares if there is one or more issues from the deceased (husband).

These are specified fractional shares that Allah has prescribed to some inheritors based on their close association with the deceased. No one is to tamper with these fractions as stipulated by Allah and it is when the shares of these group of people have be taken care of that the rediuals will be shared to aganatic sharers and distant kinsmen. If nothing remained after given the shares of the Quranis heirs specified in the Quran, then nothing goes to the other two groups because they also have their close relations as well. 


\subsection{The Principles of Hajib.}

Hajib is derived from $\mathrm{Ha}-\mathrm{ja}-$ ba which means to disallow. Hajib is the person who disallows the other heir from inheritance. Mahjub is the person disallowed. The presence or existence of person may disallow another person from sharing in the inheritance of a deceased.

e.g. A muslim died leaving behind an estate worth $\# 5,000,000$. Calculate the shares of each of his survivors who are father, son, grandfather, mother and grandson.

Survivors

Yusuf (father) $\frac{1}{6} \quad 1$ of $6=\frac{1}{6} \times \# \frac{5000000}{1}=\# 833,333$

Ali (Son)

Grandfather

$$
\mathrm{R} \quad 4 \text { of } 6=\frac{4}{6} \mathrm{x} \# \frac{5000000}{1}=\# 3,333,333
$$

Tawa mother $\frac{1}{6}$

Hussain Grandson

$$
1 \text { of } 6=\frac{1}{6} x \# \frac{5000000}{1}=\# 833,333
$$

$\mathrm{X}$

In this case, the presence of a father disallows a grandfather from inheriting here and the presence of a son disallows a grandson too from inheriting from the deceased. Howver, Hajb is not applicable to neither husband and wife. No one can disallow the other.

\subsection{The Principle of Awl and Radd.}

Awl is increase and Radd means Return. The increase or excess that occurs after the formal legal distribution is what we call Awl. This is what remains from part of inheritance of a deceased after all the existing inheritors have been given their shares accordingly.

e.g. A muslim died and left behind a daughter, a father and two sisters. If his property was valued at \# $8,000,000$, calculate the shares of each of his survivors.

Survivors 6

Daughter $1 / 2 \quad 3$ of $6=\frac{3}{6} \times \# \frac{8000000}{1}=\# 4000000$

Father $\frac{1}{6} 1$ of $6+R=2=\frac{2}{6} \times \# \frac{8000000}{1}=\# 2666666$

2 Sisters $\frac{1}{6} 1$ of $6=\frac{1}{6} x \# \frac{8000000}{1}=\# 1333333$

The remaining property that we have after the formal legal distribution has been made is called Radd.

e.g. A muslim died leaving behind two daughters and a father. What will be the shares of each of his survivors if his property was valued at \# 7,000,000.

$\begin{array}{lll}\text { e.g. } & \begin{array}{l}\text { Survivors } 6 / 7 \\ 2 \text { daughters } \frac{2}{3}=\end{array} & 6 \text { of } 6=\frac{6}{7} x \# \frac{7000000}{1}=\# 6000000 \\ \text { Father } \frac{1}{6}= & 1 \text { of } 6=\frac{1}{7} x \# \frac{7000000}{1}=\# 1000000\end{array}$

In case of Radd, only the male Agnatic is entitled to it.

e.g. A muslim died and left behind two sisters, two daughters and her husband. If her asset was valued at \# $9,000,000$, what will be the shares of each of his survivors?

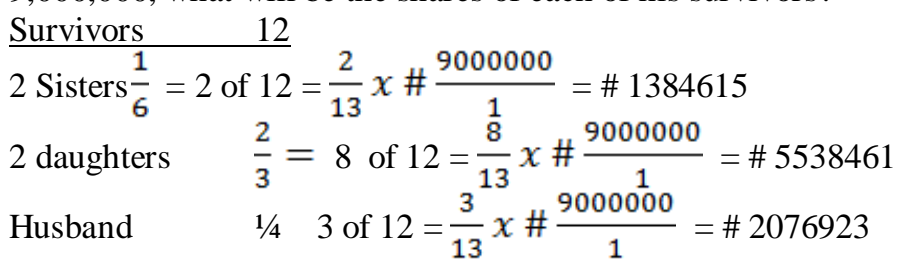

\subsection{Treating Some Cases.}

7.1.1. Case One. The total assets of a deceased was put at \# 5,000,000, his survivors were husband, 2 daughters and a brother, calculate the shares of each of the survivors. This deceased had different relationship

\begin{tabular}{|c|c|c|}
\hline fors & 12 & \\
\hline
\end{tabular}
to the inheritors. She was a wife to one, mother to two and a sister to another. 
2 Daughters $\frac{2}{3} 8$ of $12=\frac{8}{12} x \# \frac{5000000}{1}=\# 3333333$
Brother R $\quad 1$ of $12=\frac{1}{12} x \# \frac{5000000}{1}=\# 416666$

7.1.2. Case Two. Another deceased's assets was valued at \# 7,000,000, calculate the shares of each of the survivors which include husband, a daughter and a brother. The deceased in this case was a wife to one, mother to another and a sister to the other.

(2) $\underline{\text { Survivors } 4}$

$\begin{array}{lll}\text { Husband } & 1 / 4 \quad 1 \text { of } 4=1 / 4 \times \# \frac{7000000}{1}=\# 1750000 \\ \text { Daughter } & 1 / 2 & 2 \text { of } 4=\frac{2}{24} \times \# \frac{7000000}{1}=3500000 \\ \text { Brother } & \mathrm{R} & 1 \text { of } 4=1 / 4 \times \# \frac{7000000}{1}=1750000\end{array}$

7.1.3. Case Three. The estimate property of a deceased was put at \# $6,000,000$, was survived by a husband, 2 daughters, a brother and a father. What would be the shares of each of the survivors? The deceased had different association to the inheritors, was wife to one, mother to two, sister to another and was a daughter herself to the father.

(3)Survivors 12

Husband $1 / 4 \quad 3$ of $13=\frac{3}{13} x \# \frac{6000000}{1}=\# 1384615$

2 daughters $\frac{2}{3} 8$ of $13=\frac{8}{13} x \# \frac{6000000}{1}=\# 3692307$

Brother R

father $\quad \frac{1}{6} 2$ of $13=\frac{2}{13} x \# \frac{6000000}{1}=\# 923076$

7.1.4. Case Four. Another deceased whose property was put at \# 8,000,000 was survived by a husband, mother, 2 daughters and a brother, what would be the shares of each of the inheritors? This deceased was wife to husband, daughter to mother, mother to 2 daughters and sister to brother.

(4) Survivors $12 / 13$

Husband $1 / 4 \quad 3$ of $13=\frac{3}{13} x \# \frac{8000000}{1}=\# 1846153$

mother $\frac{1}{6} \quad 2$ of $13=\frac{2}{13} x \# \frac{8000000}{1}=\# 1230769$

2 Daughters $\quad \frac{2}{3} \quad 8$ of $13=\frac{8}{13} x \# \frac{8000000}{1}=\# 4923076$

Brother R $\mathrm{X}$

7.1.5. Case Five. The property of a deceased muslim in the $5^{\text {th }}$ case was estimated to the sum of $15,000,000$. He willed \#2,500.000 for a mosque project, had a loan of \#3,000,000 from his bank in addition to $\# 1,500,000$ he owed his friend. What would be the shares of his survivors among whom were a son, two daughters, a grandson, a wife, a mother and his uncle? (This deceased was father to a son \& 2 daughters, grandfather to a grandson, husband to wife, son to mother and uncle to his uncle).

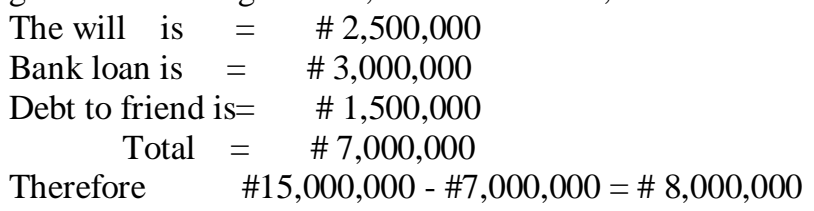

So, amount left is $=\# 8,000,000$.

(5). Survivors 24

A Son R]

2 daughters R] 17 of $24=\frac{17}{24} \times \# \frac{8000000}{1}=\# 5666666$
A Grandson
A wife
$\frac{1}{8}=3$ of $24=\frac{3}{24} x \# \frac{8000000}{1}=\# 1000000$
A mother
$\frac{1}{6}=4$ of $24=\frac{4}{24} \times \# \frac{8000000}{1}=\# 1333333$ 
An uncle $\mathrm{x}$

For the 1 son and 2 daughters \# $5666666 \div 4=\# 1416666.5$

Son will take \#2833333 while each of the daughters take \#1416666.

7.1.6. Case Six. The property of a deceased muslim was put at $\# 20,000,000$, if he willed $\# 2,000,000$ for the motherless home, paid a mortgage of \#5,500,000 and settled another debt of \#2,500,000. Calculate the shares of his survivors who included 2 wives, 2 daughters, 2 sons, a father, a grandfather, 1 grandson and a niece.

(This deceased was husband to 2 wives, father to 2 daughters \& 2 sons, son to a father, grandson to grandfather, grandfather to grandson and niece to niece).

$\begin{aligned} \text { The will } & =\# 2,000,000 \\ \text { Mortgage } & =\# 5,500,000 \\ \text { Debt } & =\# 2,500,000 \\ \text { Total } & =\# 10,000,000\end{aligned}$

Therefore \#20,000,000 - \#10,000,000 = \#10,000,000

Amount left $=\# 10,000,000$.

(6). Survivors 24

2 wives $\frac{1}{8} 3$ of $24=\frac{3}{24} \times \# \frac{10000000}{1}=\# 1250000$

2 daughters $R$

2 sons $\quad$ R 17 of $24=\frac{17}{24} x \# \frac{10000000}{1}=\# 7083333$

Father $\quad \frac{i}{6} 4$ of $24=\frac{4}{24} \mathrm{x} \# \frac{10000000}{1}=\# 1666666$

Grandfather $\mathrm{x}$

Grandson $\mathrm{x}$

niece $\quad x$

Therefore to get the shares of 2 sons and 2 daughters, we shall double the sons making 4 sons and 2 daughters = 6.

So divide shares of sons and daughters as \#7083333 $\div 6=\# 1,180,555$.

So each son takes \#2,361,111 and a daughter takes \#1,180,555.

\subsection{The Case of a Missing Person.}

A missing person is called Mufqud al - Khabar who is considered living with regards to his property and dead to others until his death is ascertained or such a long time passes away in his absence that none of his contemporary remains alive.

According to some legal sources, 90 years from the date of his birth is for keeping the property in suspense because no one can live longer than this period. (Shafihi). Yushua Sodiq (1996), [15] makes reference to Hanafis who hold the view that a family should wait for the return of a missing person between sixty to ninety years while the Malikis hold the view that they should wait for four years. This view was based on the decision of Umar bn Khattab the second caliph who ruled between 634 to 644 c.e.

In the administration of the law however, the rare case of extraordinary is not taken to account because the axis of the law revolves in the ordinary course of occurrences.

To Shafihi, property of the missing one is kept in suspense according to the decision of Imam or judge. If he decides that ordinarily no one can live longer than the period during which he was absent, he divides the estate among his heirs.

The share of a missing one is preserved from the property whom he inherits i.e. if he belongs to those who exclude the present persons, nothing is to be paid to such person because he may emerge. But the whole property shall be kept in abeyance. And if he does not exclude them, every one is given the least of his share on the supposition of the life of the missing person and also of his death.e.g.

In this case, a deceased muslim whose property was valued at \#12,000,000 after death left his wife, a daughter, uncle and his (father Missing) behind. What would be the shares of each of his inheritors?

( Here, the deceased was husband to wife, father to daughter, uncle to uncle and son to the missing father).

$$
\begin{array}{lll}
\begin{array}{lll}
\text { Survivors } & 24 \\
\text { Wife } & \frac{1}{8} 3 \text { of } 24=\frac{3}{24} \times \# \frac{12000000}{1} & =\# 1500000 \\
\text { A Daughter } & \frac{1}{2} 12 \text { of } 24=\frac{12}{24} \times \# \frac{12000000}{1} & =\# 6000000 \\
\text { Father(missing) } & \frac{1}{6} 4 \text { of } 24=\frac{4}{24} \times \# \frac{12000000}{1}=\# 2000000 \\
\text { Uncle } & \text { R } 5 \text { of } 24=\frac{5}{24} \times \# \frac{12000000}{1}
\end{array}=\# 2500000 .
\end{array}
$$


In this case, the share of the father although missing should be kept aside because he may show up later since he has not been confirmed dead.

\subsection{The Case of an unborn heir.}

In the case of an - unborn heir, he cannot inherit until he is born alive. His share should be put aside pending his delivery but the share to be kept is that of a male child. However, according to the Maliki school, the whole estate should be saved pending the delivery of the child before distribution.

In case of mass death, the surviving relatives should share their property.

\subsection{The case of Wasiyyah - Will.}

Wasiyyah is derived from the Arabic word wasa which means he conveyed. Wasiyyah is a gift of property by its owner to another contigent on the giver's death. In Islamic law, a muslim is allowed to will out not more than $1 / 3$ of his property and he cannot make a will to his legal Quranic heirs either to increase or decrease their shares. After a person's death, his debt if any should be paid first, then his bequest and distribution of the remaining property among his heirs. (Abdurahman 2008). [16]

If wasiyyah is made for a dead person, it will go to his heirs. The will could be made orally or through writing. Dr. Muhammad Bashir al- Mufashi,(2008) [17] opines that If it was made by someone who poisons himself, it is not valid.

Wills can be made in favour of a non-muslim, educational, charitable and religious institutions. A will made on a previous will makes the previous one invalid. Wills made in one's lifetime can only be executed by others after death. However, the one whom the will is made for may accept or reject it if he likes.

\section{Conclusion.}

Abdul Hamid Siddiqui (2007) [18] sums up the considerations for the Islamic Law of inheritance which includes to break up the concentration of wealth from the hands of few individuals and to spread it out in the society. To respect the rights of individual's ownership and property earned through honest means. To make people realize that they are not absolute owners of property and so they should spread it in the way Allah stipulates. To consolidate the family system which is an integral part of an Islamic society. And to give incentive to work and encourage economic activities approved by Islam. Moreso, to encourage more muslims to acquire knowledge of inheritance in order to be able to tackle tasks and issues related to this subject in a practical and more pragmatic manner. Sohail S. Hussaini (2006) [19] describes the law if inheritance as a gift of wisdom for mankind from the Supreme Being.

\section{References.}

[1] Abdul Hamid Siddiqui, Inheritance in Islam, (IslamOnline.net-Shariah and Humanity 2005).

[2] A. H. Siddiqui, The System of Inheritance in Islam ( www.reading islam.com 2007) assessed 02/10/2013.

[3] Y. Sodiq, An Analysis of Yoruba and Islamic Laws of Inheritance, (Muslim World Hartford, Conn. 1996) v86, p313-33 JI/ o '96. (aiu Library).

[4] Islamic Inheritance Jurisprudence. (Wikipedia, the free Encyclopedia http://en.wikipedia.org/wiki/Islamic inheritance jurisprudence assessed 09/02/2013/

[5] S. Sapp, Religious Views on Legacy and Intergenerational Transfers, Generations, (San Francisco, Calif. 1996) v20 p31-6 Fall '96. (aiu library).

[6] Inheritance Critical Thoughts, Inheritance in Islam, (Madrasah Arabia Islamia-Azaadville 2009), www.islamsa.org.za/library/pamphlets/inheritance-in-islam.htm assessed 25/01/2013.

[7] Muhammad The Prophet of Islam- The System of Inheritance in Islam, (Position Paper on Islamic Inheritance 2009) www.islamicity.com

[8] Y. Sodiq, An Analysis of Yoruba and Islamic Laws of Inheritance, (Muslim World Hartford, Conn. 1996) v86, p313-33 JI/ o '96. (aiu Library).

[9] Islam's Viewpoint on Wills, Bequests and Inheritance, (Wikipedia, the free enciclopedia 2013)..

[10] M. A.Rauf, Inheritance in Islam, (Al- Saadawi Publications 1999).V.A.

[11] W.A. Coggins, (2004), Succession in Traditional Islamic Law, Journal of the Missouri Bar 60 no 4 180-4 JI/ Ag. 2004. (aiu library).

[12] A. Salahi, Arab News, (www.arabnews.com 2004) assessed 28/01.2013.

[13] A. Hussain, Sociology-The Islamic Wills, (www.islam101.com/sociology/wills.htm 2004).

[14] A. Hussain, Sociology-The Islamic Wills, (www.islam101.com/sociology/wills.htm 2004).

[15] Y. Sodiq, An Analysis of Yoruba and Islamic Laws of Inheritance, (Muslim World Hartford, Conn. 1996)

[16] Abdurahman, Inheritance in Islam. (Nice Article on Inheritance in Islam 2008), jannah.org/madina

[17] M.B. Mufashi, Inheritance in Islam. (jannah.org/madina 2008), assessed 23/01/2013.

[18] A. H. Siddiqui, The System of Inheritance in Islam ( www.reading islam.com 2007) assessed 02/10/2013.

[19] S. S. Hussaini, The Laws of Inheritance in Islam, (Published by Outskirts Press inc 2008). 